\title{
ENTREVISTA
}




\section{NO CALOR DA OBRA: ENCONTROS COM A PRODUÇÃO CULTURAL CONTEMPORÂNEA Entrevista com Luiz Tatit}

Músico graduado na Escola de Comunicações e Artes da USP, cancionista e professor do Departamento de Linguiística da mesma universidade, autor de inúmeras canções desde a sua ligação com o grupo Rumo, nas décadas de 1970 e 1980, assim como de uma dissertação de mestrado e duas teses, uma de doutorado e outra de livre-docência, além de dezenas de artigos em revistas acadêmicas, sempre tomando como objeto de reflexão e teorização a canção, Luiz Augusto de Moraes Tatit sintetiza em sua trajetória um pouco daquilo que ele mesmo formulou como a condição algo "acrobática" do compositor de canções populares no Brasil. Transitando entre criação livre e inventiva, na linha de frente da chamada "vanguarda paulista", que se realizou com força e diversidade nos trabalhos de Arrigo Barnabé, Itamar Assumpção e Hermelino Neder, e o investimento na construção de um rigoroso modelo teórico de análise semiótica, capaz de articular a produção de sentido nas camadas textuais, musicais e interpretativas da música popular cantada, Luiz Tatit pertence a uma geração de artistas-intelectuais que segue explorando as potencialidades desse modo de ser tão peculiar de nossa cultura.

Esta entrevista foi concedida durante sua rápida passagem por Curitiba, cumprindo programação ainda uma vez exemplar dos traços acima descritos: logo após duas palestras de caráter acadêmico, uma na UFPR, para os alunos do Setor de Ciências Humanas, Letras e Artes, e outra no Conservatório de Música Popular da Fundação Cultural de Curitiba, e às vésperas do espetáculo de lançamento na cidade de seu primeiro disco solo, Felicidade (DABLIÚ, 1998). 
Marcelo Sandmann - Certamente uma das contribuições mais interessantes do seu trabalho como estudioso da canção diz respeito ao fato de você tentar compreender a canção popular brasileira no que ela tem de específico, não numa teorização restrita do text९ ou da música separadamente, mas sim procurando entender a conjunção das duas coisas. Uma das idéias fortes de tal formulação é a de que a canção popular brasileira parte da fala, isto é, existe na fala uma melodia latente, potencial, e uma vez que essa melodia é explicitada e fixada, a fala se transforma em canção. Em seu estado original, a fala não é temperąa, não recebe uma fixação muito precisa em termos sonoros. No caso da canção popular, percebe-se que essa fala que se transforma em canção tem encontrado, em geral, suporte em sistemas de organização musical como o tonalismo ou o modalismo - é dentro de tais sistemas que os compositores populares normalmente operam. Por que a canção popular parece sentir-se tão pouco à vontade no que diz respeito à utilização de outros modos de organizar o discurso musical, como por exemplo, um cromatismo mais rigoroso, o atonalismo, o dodecafonismo (talvez a experiência paradigmática no contexto brasileiro seja o caso de Arrigo Barnabé)? Por que a resistência dos compositores em enveredarem por esses caminhos, assim como do público em entender isso como canção popular, já que a fala, na origem, não é música? Haveria motivos de ordem mais natural, fisiológica ou psicológica, para essa preferência, ou as motivações seriam de ordem cultural, em razão de uma dada tradição musical que nos serve de modelo?

Luiz Tatit - Em primeiro lugar, creio que a canção não incorpora elementos cromáticos como a música erudita faz, no sentido de aprimorar sua linguagem ou pelo menos trazer novidade para sua estruturação, porque para ela este não é um problema. A canção nunca teve esse problema de utilizar cromatismo, diatonia, isso não importa muito $\mathrm{cm}$ seu contexto, isso não é sua tradição. Para a canção, a escala diatônica tem o mesmo sentido que a escala cromática, não foi por aí que se formularam os problemas da canção, ou o problema musical não chegou até a canção. Em scgundo lugar, a fala fornece como matéria-prima uma série de microtonalidades, essa entoação da gente que não afina, que oscila, que é um recurso extraordinário para se utilizar e tem sido utilizado até inconscientemente por muitos autores, e por alguns até conscientemente. São essas inflexões que estão na conversa diária e que, quando a canção é fixada, são temperadas. Ạssim, se na canção não há cromatismo, há microtonalidades que lhe fornecem elementos que podem ser explorados 
em favor de uma unidade dentro da composição. Por fim, o fato de usar ou não tais elementos, depende muito da formação do cancionista, que raramente terá estudado estas etapas da música. Isso quase não chega a constituir um problema para este artista, de maneira geral. É uma necessidade "de fora para dentro". Um exemplo que eu noto é o da Tropicália: os artistas se sentiram extremamente desconfortáveis com as exigências que o pessoal do concretismo fazia no sentido de inovar, do ponto de vista musical, de haver uma tendência a músicas menos conservadoras, menos comerciais, inclusive houve um programa no Rio, se não me engano chamado Vertigem, que aproximava dois autores, um antigo e um novo, na canção brasileira, e que aproximou, na ocasião, Caetano Veloso e Arrigo Barnabé, que acabara de aparecer no festival [da Tupi]. Foi quando eles se conheceram e tornaram-se amigos. Arrigo Barnabé fez essa pergunta para Caetano Veloso: "Eu me decepcionei um pouco com a Tropicália porque imaginava que após aquelas experiências todas vocês enveredassem por uma música mais atonal...", e Caetano respondeu-lhe: "Isso é uma coisa pra você fazer, não pra mim... Eu espero que você faça isso". Foi uma resposta assim, na lata. Caetano formou-se nos auditórios da Rádio Nacional, ouvindo Emilinha Borba, Dalva de Oliveira, essa é a sua formação, ele se instruiu musicalmente ouvindo canções da Rádio Nacional. Essa história de trazer dodecafonismo ou atonalismo passava longe das suas aspirações, não tinha absolutamente nada a ver com ele, chegando mesmo a incomodar-se com certa insistência de Augusto de Campos, que sempre gostou de música de vanguarda, dizendo-lhe que achava até bonito, interessante, mas que não queria fazer aquilo, tinha uma verdadeira aversão. Inclusive de julgar-se que o que ele fazia fosse inspirado no concretismo, ele não tinha nada a ver com isso, nem na letra, nem na melodia. Mas há ainda uma outra dimensão em sua questão, que diz respeito às razões de as músicas saírem modais ou tonais. Esta é uma outra questão, que já tratei em outros contextos. Nós temos um imaginário que todos os antropólogos e mesmo Freud identificaram em nossa mente, um componente narrativo muito claro que se manifesta numa tensão entre incorporação de objeto e perda de objeto. Nós vivemos em harmonia enquanto pensamos que estamos com o objeto dentro de nós; ao mesmo tempo que nós perdemos o objeto, perdemos a harmonia, mas ganhamos sentido, pois nos lançamos à busca do objeto - sentido é direção, ir atrás de alguma coisa. A música, todas as peças musicais, mesmo as eruditas, vivem dessa tensão. Quando o motivo repete, significa que o objeto está dentro do sujeito, não se separa, 
ou seja, há identidade; de repente, surge o contra-motivo, para fazer o contraste, daí perde-se o objeto inicial. A nossa tendência auditiva é esperar que ele volte, ficamos o tempo todo esperando. Isso na canção popular é terrivel, por isso existe refrão: a única vantagem de se ir para a segunda parte é para retornar-se depois ao refrão. É a mesma estrutura narrativa dos contos de fada, em que o sujeito perde o objeto e busca recobrá-lo, alguém ia casar-se com a princesa mas ela foi raptada, então o resto da história é salvar a princesa; o resto da história musical é voltar ao refrão. Há, portanto, uma perspectiva, um imaginário humano, que é muito forte, e de que Schoemberg não sabia, ou não levou em conta, em seu projeto de criar um sistema que não voltasse mais aos elementos essenciais de um refrão: ele estava mexendo não com a história da música, ele mexia com o imaginário humano, que precisa de narrativa, ou então não se envolve. Por que até hoje não se assimilou a música dodecafônica? Já era tempo, já faz um século, ainda mais agora que as coisas vão num ritmo muito mais rápido. É o imaginário humano que está sendo conturbado. A música espontânea sai tonal, com partes que sempre retornam a um início, porque há toda uma estrutura narrativa que se está manifestando também nos sons. O sujeito que perde o objeto quer reencontrá-lo.

Benito Rodriguez - Ainda nessa linha, a natureza peculiar da canção, como objeto, produz diversos equívocos de abordagem, uma vez que ao serem utilizados instrumentos de análise centrados apenas nas teorizações musicais, ou nas poéticas da cultura letrada, para abordar respectivamente suas dimensões musicais e textuais, produz-se certa rarefação e afrouxamento destes componentes em comparação à música enudita ou à cultura literária. Seria exagero afirmar que o cancionista não é nem músico, nem poeta, mas alguma outra coisa?

$L T$ - Acho que é bem isso mesmo. Os parâmetros de análise de uma canção não podem levar em conta o que já foi desenvolvido como critério para se analisar uma música ou para analisar a literatura. Os critérios literários não servem para a canção, uma letra de canção não é menos boa por não seguir o cânone do ponto de vista sonoro, ou de elementos imagéticos, ou por não ser digna dos modelos da poesia; ela não deixa de ser boa por causa disso. Da mesma forma, uma canção que não traga novidades ou elementos musicais interessantes em termos harmônicos e tal, não deixa de ser, às vezes, maravilhosa. Uma canção de Roberto Carlos, às vezes com dois ou três acordes, consegue falar de um certo 
conteúdo de tal modo que, todos que queiram operar sobre o mesmo conteúdo têm que lançar mão daquela música, como "Detalhes", por exemplo. Uma canção musicalmente simplicíssima, e mesmo como canção. No entanto, é um tipo de conteúdo que ele trata ali que se alguém for falar daquilo, tem que falar daquele jeito, não há outra maneira. Creio já estar consolidada a diferença entre estes universos de criação. Vai-se da água para o vinho: canção é tão diferente de música e de literatura quanto é diferente de história em quadrinhos. Até mais próxima da história em quadrinhos, porque em ambas operam dois sistemas simultaneamente, texto e melodia numa, e imagem e texto na outra. São coisas completamente diferentes. E é difícil porque mesmo quem sabe disso acaba, sem querer, avaliando a canção como sendo melhor ou pior na medida em que consegue se espelhar nas artes eruditas. Isto tudo é central no meu trabalho, a demonstração desta especificidade. Mas ela precisa ser demonstrada enquanto "não se sabe"; quando esta já for uma compreensão generalizada, que a canção é uma coisa específica, não será mais preciso separá-la dos demais objetos, identificando-a como uma realização boa ou ruim, junto às demais formas de realização artística, ao lado da música, da literatura, do cinema, de tudo. Nesta fase que vivemos, ainda é preciso mostrar que é uma produção específica, senão perde-se a condição de avaliá-la. Hoje à tarde em minha palestra no Conservatório de MPB, o público dizia: "Mas há canções que são uma porcaria e outras que são boas", mesmo depois de tudo o que eu já falara em torno desta questão... [risos] Bem, na verdade foi só um rapaz que levantou esse problema. É uma visão muito maniqueísta. Ele perguntava: "Por que uma canção é boa ou ruim?". Eu respondi que levantava todos aqueles critérios e todo um instrumental analítico para mostrar como é possível descrever de outra forma a canção e até entrever, por detrás de canções aparentemente feitas com fórmulas prévias, como é o caso do pagode, da axé-music, que já têm alguns modelos pré-estabelecidos para serem compostas, que tendemos a achar ruins, perceber que, às vezes, eles conseguem obter resultados maravilhosos fazendo desse jeito. Há músicas cantadas pela Ivetinha [Sangalo], da Banda Eva, que são maravilhosas, são músicas de uma empolgação fantástica, que conseguem expressar tudo o que eles queriam. Devemos desprezar esse tipo de conquista? Aquilo é demais. Como o É o Tchan, houve um momento em que eles estavam demais. Depois torna-se excessivo, o próprio público deles começa a se cansar, já não é o mesmo impacto, e a gente acaba condenando essa repetição exaustiva de um filão. Mas isso já é um 
fenômeno de mercado, não há como interferir nisso. Mas que eles obtiveram uma dimensão estética indiscutivel é certo, a tal ponto que eu até escrevi num artigo da Folha de S. Paulo, que eu não vi nada mais completo em termos de espetáculo do que o grupo É o Tchan, em comparação com os espetáculos dos artistas norte-americanos, como Michael Jackson, só que com elementos brasileiros, como o rebolado, a exaltação da bunda, tipicamente brasileira, mas que consegue os mesmos efeitos que as quebradas do Michael Jackson e todos os clipes maravilhosos que se produzem lá. Pois o grupo baiano faz um clipe "ao vivo" aqui. Em cada show uma exuberância tremenda. Então não se pode deixar de notar isso.

Com a linguagem própria da canção, que já não é apenas letra e melodia, mas inclui o clipe, pois incorpora-se o aspecto visual também, estamos diante de um outro produto, que deve ser avaliado a partir de outros critérios, não dá mais para desenterrar critérios eruditos para ver algo que está aí, vivo, mexendo com todo o mundo, causando verdadeiro furor. A gente reclama de outras coisas: não há espaço para outras músicas, há muita gente fazendo discos interessantes, propostas novas, e não há espaço para todos. Mas quanto a isso, nem por milagre haveria tal espaço. Atualmente uma produção simples de um disco custa em torno de três mil reais, se não for preciso pagar músicos. De uma classe de uns duzentos alunos, há sempre uns quinze que já gravaram seu disco. Antes de eu ter o meu, eles já tinham os deles... [risos] É tão fácil gravar agora! Imagine se fôssemos procurar espaço para todos eles na rádio. Nem se houvesse mil vezes mais rádios do que há hoje em dia. Então, não creio que haja muito o que lamentar, nem o que fazer quanto a esta situação. Por um lado, os filões estão já decididos; por outro lado, pessoas cujas carreiras pareciam já enterradas ressurgiram, como é o caso do Tom Zé, que estava liquidado. Foi retomado, não sei de onde, por mero acaso. Muita gente está entrando no mercado por mero acaso. Luiz Melodia também parecia que não fosse ter mais qualquer chance e foi recuperado. Sob esse aspecto, estamos vivendo uma fase maravilhosa do mercado, que está inteiramente com a música brasileira, a música de fora, especialmente a norte-americana, está lá em vigésimo lugar, não está nem competindo com a música brasileira. Nunca houve isso em nossa história. Assim, precisamos ter critérios até mais sofisticados atualmente: não é só questão de melodia e letra, mas destas e da linguagem do espetáculo, do clipe. Tudo isso está entrando agora na configuração desse objeto que é a canção. Se não tivermos tais critérios, vamos ficar 
reclamando a vida inteira que isso seria fajuto, um modo de fazer comércio fácil, sem entrever peças belíssimas por trás de canções, às vezes em função de um arranjo chapado demais - embora os arranjos tenham que ser simples, sem o que o grau de popularidade visado não será alcançado. Há um certo equívoco de apreciação. Isso que o Caetano Veloso faz desde a Tropicália, gravar músicas consideradas do terreno brega, tem sido extremamente benéfico: ele demonstra que basta retirar o arranjo feito para atender o mercado que se pode mostrar coisas que estão por trás, na canção, por vezes de forma extremamente límpida, cristalina, de beleza, de adequação entre melodia e letra, que gravadas à maneira dele não fariam sucesso, mas que ele revela à elite estarem lá dentro, quando esta elite já não consegue perceber em razão desta tela que se impõe entre o objeto e o sujeito, por já não termos mais um "gosto pessoal". Nosso "gosto" é social, é o da comunidade que freqüentamos: não podemos gostar de uma música que nossa comunidade não aceita. No fundo, temos a sociedade dentro da cabeça e acabamos nos comportando segundo seus parâmetros, senão não haveria o superego, mas é preciso sermos capazes de recobrar a capacidade de sentir. As pessoas têm vergonha de gostar de Claudinho \& Buchecha, por exemplo. Celso Fonseca, que é um músico excelente, gravou deles "Conquista", e eu fiquei chapado de ouvir aquilo. Diferentemente do Caetano, ele é um artista sem grande projeção. Arriscar-se nesta estratégia pode criar dificuldades para sua inserção. E ele faz um show chique, com músicas excelentes, e inclui essa música linda, que ninguém sabe de onde veio... Está em qualquer emissora de rádio, só que cantada de outro jeito. Tudo isso precisa ser reavaliado, até pra gente não ficar apenas reclamando, não só da música, mas da vida. Na verdade, o que está aí a gente precisa apreciar também, há muita coisa interessante aparecendo nas rádios, que vem dessa instrumentação mais sofisticada, do avanço eletrônico, que está conseguindo produzir coisas muito boas.

Patrícia Cardoso - Você fala de um movimento que é de um grande público em direção a esse público, por assim dizer, mais especializado; a música produzida para o grande público acaba atingindo, por vias indiretas, as audiências mais sofisticadas. Você acredita que seja possível o inverso? É possível o grande público sensibilizar-se com alguma coisa feita para uma camada especializada?

$L T$ - Até um certo ponto, sim. Por exemplo: a luta do Arnaldo Antunes é essa. Ele faz uma coisa extremamente requintada, e o projeto de vida 
dele é que seu trabalho seja extremamente popular. Ele se empenha nisso todo o tempo. A cada ano é um disco novo, a cada ano ele vai a todos os programas de televisão, desde o Raul Gil. Seja o que for, ele está presente, nos shows da Globo, ele sempre arruma um jeito de ser convidado pra entrar, pra se apresentar, ou seja, ele quer ter uma penetração de massa a todo o custo. E é o que há de mais requintado em termos de relação melodia e letra, até foge um pouco a essa questão da narrativa a que me referia há pouco. Ele tenta burlar esse gosto fácil e tenta fazer com que as canções sejam palavras de ordem mais concreta, no sentido do Concretismo. E consegue uma boa penetração, pelo fato de ter participado dos Titãs, para o tipo de trabalho que faz, e ele visa a isso. Mas creio que há níveis diversos nesse processo. Coisas que Caetano Veloso faz e que nós achamos requintadas chegam facilmente a um público maior. No caso de algumas músicas, quase que a um público de massa. Não diria que chega propriamente à massa porque se tivermos como parâmetro o Só pra Contrariar, nem chega perto. Também é o caso do Gilberto Gil. Então isso tem acontecido, inclusive devido ao fato de algumas músicas mais requintadas ainda, que têm menos projeção, conseguirem vender, ao menos, 100 mil cópias. Isso é bastante, significa que muita gente ouviu aquilo e, às vezes, a gente até se surpreende com pessoas que achamos que jamais conheceriam determinada música muito requintada e, de fato, já ouviram, já sabem até assobiar o tema, eu já me espantei com isso. Aliás eu creio que esse fenômeno, da música refinada chegar ao grande público é mais comum do que a música popular chegar à elite.

$P C$ - Tudo é uma questão do mercado permitir. Nomes como Djavan, por exemplo, conseguem, mas em cada disco que ele lança, há uma música na novela, e essa canção vai chamar esse público. Então não é apenas uma questão inerente à obra, não é ?

$L T$ - Sem dúvida. Acho que há um aspecto inerente à música dele que tem potencial de popularidade; um outro artista poderia fazer a mesma música e não ter a mesma aceitação. Onde investir acontece, onde não investir, não. Isso é claro, essas são outras leis, de mercado. Isso interfere em tudo, mesmo em coisas que são inteiramente casuais. Ele pode ser amigo de alguém que pela primeira vez pôs a canção em uma novela; depois disso continuaram a incluí-lo por ter dado certo. Isso não dá pra controlar. Ontem o Celso Masson, da Veja, me ligou tentando resolver esse problema. Eu falei: "Desista." [risos]. Ele insistia: "Por que no caso 
de duas músicas iguais, preparadas por dois artistas diferentes, mais ou menos do mesmo talento resultam em uma ser um sucesso e outra não?", como se eu pudesse, na hora, por telefone, responder a isso... Se eu soubesse a resposta, já teria vendido 2 milhões de discos. Aliás, já telefonaria direto pra Warner e venderia a idéia.

Luís Bueno - Eu gostaria de voltar à questão do valor. É verdade que não faz sentido menosprezar Roberto Carlos porque existe Gilberto Gil, mas existem canções mais eficazes do que outras. Mesmo dentro da obra de um artista consagrado, é possível verificar isso. Então, existiriam sim, canções ruins, ou infelizes ou ineficazes. Isso existe?

$L T$ - Olha, eu realmente não sei mais. Nem se existe canção ruim, nem se existe canção boa. Imagino que atinge-se um grau de eficácia. Aliás, ao escrever meu primeiro livro, escolhi como título Canção: eficácia e encanto [1986], porque eu via sempre que o encanto e a eficácia têm entre si um limite que não sei exatamente onde está, onde uma acaba e o outro começa. $O$ encanto seria ligado a essa dimensão inerente, esse segredo que às vezes as canções têm e mesmo alcançando grande popularidade permanece ali, oculto. $O$ outro lado, a eficácia, é a possibilidade de o encanto aparecer, e às vezes não aparece. Então não sei mais se existe essa divisão entre bom e ruim em canção. $O$ que se vê é uma certa apelação. Percebe-se que algo deu certo, então tenta-se fazer exatamente o mesmo, mas isso é muito antigo, não é de agora. Lembro, por exemplo, em 1967, mais ou menos, Jair Rodrigues fez um sucesso estrondoso com a música Deixa isso pra lá [Alberto Paz / Edson Menezes, 1964]. Essa história de "mercado" estava ainda começando no Brasil, só Roberto Carlos já conhecia o mercado nessa época, ele já fazia música para o mercado desde o início. O pessoal da MPB não tinha muito isso, eram aqueles sambinhas e tal... Bom, deu certo e a gravadora imediatamente contratou alguém pra fazer uma outra canção para o Jair Rodrigues onde ele gesticulava verticalmente, ao invés de movimentar as mãos horizontalmente... [risos] E daí a música era assim: Eu andava tão certinho / a vida me chutou / fui sincero com você / você me chutou /Agora vou assim / de ziguezague, ziguezague / você quer me ver assim / de ziguezague, ziguezague, que era paralelo a: Deixe que digam / que pensem / que falem..., quer dizer, exatamente a mesma coisa, inclusive com um certo excesso, nas reiterações, a vida me chutou, você me chutou, usando o mesmo verbo, parece que nem havia tempo de desenvolver a idéia [risos], era preciso lançar no mesmo mês pra pegar o embalo. $\mathrm{Na}$ 
época eu era praticamente criança, um pré-adolescente, mas percebia que aquilo não pegava e realmente não fez sucesso nenhum, só fez sucesso a primeira, tanto que ninguém conhecé a segunda. Então as gravadoras têm também um grave problema: se os' produtos não forem bem feitos, no sentido de haver um certo engenho por trás deles, não dá certo. E já houve várias experiências nesse sentido. Desse modo, é curioso observar que quando se explora um filão, há um certo cuidado de não deixar os produtos se banalizarem demais, eles já sábem recolher, retomar velhas idéias, já há um controle que demonstrả o quanto eles são hábeis na administração do processo. Mas eles também se enganam de tempos em tempos. Então, essa "canção ruim", em princípio, eu acho que nem existe. O que há são canções que querem transmitir alguma coisa, mas, por razões diversas, acabam não transmitindo. Já essa espontaneidade não creio que seja ruim. Pessoalmente posso não gostar de uma música, de um estilo. Às vezes, no caso de grandes compositores, não gosto de sua abordagem, de seu modo de compor, embora eu saiba que se trata de um bom compositor, faz coisas boas, tem um bom alcance popular, mas não gosto daquilo. Isso porém, já é outro problema, é o território do gosto pessoal. Quando a gente faz um mínimo de ciência - e digo um mínimo, porque nunca é muito mais do que esse mínimo no caso das ciências humanas, estamos sempre num "projeto de ciência" - quando se visa uma abordagem um pouco mais isenta, o que se pode analisar são as constâncias que há por trás da produção, jamais os casos específicos. $\mathrm{O}$ que é específico corres-ponde à natureza de cada autor. Pode-se captar maneiras de fazer, as repetições, as formas de prolongar as vogais, as durações, mas cada compositor faz isso de um jeito. O Djavan prolonga de um jeito, o Roberto Carlos de outro; todos usam prolongamento de vogal, mas cada um a seu modo.

Raquel Bueno - Não sei se fica difícil responder isso, mas haveria como comparar, em termos genéricos, o modo como apreciamos a canção e o modo como apreciamos a literatura, digamos um poema? Será que o fato de o mercado para a canção ser muito maior é o que define as diferenças ou haveria motivações de natureza imanente a estes objetos?

$L T$ - Eu diria que a semiótica pode nos ajudar neste caso. Ela nos ensina a analisar tudo que significa, independentemente de se lançar, de antemão, uma idéia do que seja melhor ou pior. Analisa-se: se tem significação, isso será revelado pelo trabalho. Em geral, não vem muito ao caso a questão do valor, o que, por vezes, é uma questão pessoal do analista, 
que pode pensar olhe só que maravilha essa construção do autor etc., mas isso porque ele já gostava de antemão do que estava analisando, nada tem a ver com a análise. Sinceramente, em função dessa visão semioticista, nunca valorizo nada, senão no sentido de gosto pessoal. Nada me parece inerentemente melhor ou pior do que nada. Por vezes, pode perceber-se maior esforço em certa realização, que demandou maior dedicação do autor, até por ser mais longa, mais esmiuçada; às vezes o potencial mítico é mais forte, porque o autor é mais versado naquilo; outras vezes é o potencial narrativo que se destaca, por ser mais denso, ou seja, cada um tem seu caminho. Guimarães Rosa, por exemplo, faz a meu ver uma semiótica mítica o tempo todo, ele está o tempo inteiro analisando o sentido, e as histórias são meros pretextos para a análise da questão do sentido. Creio que sua obra é de uma profundidade absoluta, que não tem paralelo, mesmo internacionalmente. Mas não saberia dizer se a obra dele é melhor ou pior do que a de Oswald de Andrade, por exemplo. Caso houvesse quem escrevesse dentro da mesma linguagem de Guimarães Rosa seria possível comparar, mas com estilos tão diferentes, não há como fazer. Tenho a impressão de que seria preciso analisar com critérios diferentes. Há, isso é certo, um apelo afetivo maior com relação a certos autores. Penso no caso de Ivan Lins, que é um dos poucos cancionistas com sólida formação musical no meio, de cujo trabalho não gosto. Entretanto, vejo como ele é ouvido, como as pessoas gostam de suas canções, e chego a preocupar-me com o meu gosto [risos], tento ouvir outra vez, de outro jeito, e às vezes até percebo as razões que levam o público a gostar de suas canções, mas são hipóteses. Por outro lado, gosto muito mais do Peninha do que do Ivan Lins. Qual a razão disso? Esse negócio de gosto pessoal deve ser deixado de lado: quando se fala de análise, o foco deve concentrar-se no que é constante e comum a todas as canções, o específico é irredutível, nisso não entramos. É o imponderável, um terreno no qual nada é previsível. Aliás, é por isso que as coisas têm graça. Se conseguíssemos detectar a fórmula de se fazer a canção ou o poema bom, ou ruim, não haveria essa palpitação, esse movimento de obras que às vezes estão em baixa, mas depois crescem, e vice-versa. Por exemplo: eu me lembro de um exame de qualificação em um trabalho de literatura brasileira na USP, em que o candidato estudara o romance Clara dos Anjos, de Lima Barreto. Eu já conhecia este romance e, na ocasião, relera o livro em função da banca. Pois eu gosto do romance e a releitura recente tornara a afirmar essa impressão. $O$ candidato, na verdade, teve que defender sua escolha diante 
dos demais examinadores, ambos professores de literatura brasileira, que torciam o nariz para o livro, era a pior coisa no conjunto da obra do Lima Barreto, por que ele não escolhe uma coisa melhor? etc., ainda que eles gostassem do Lima Barreto, não viam interesse naquela obra em particular. Para eles, era óbvio que aquela literatura era fraca. Eu fiquei assim, com a pulga atrás da orelha, não querendo entrar no terreno deles, mas pensando comigo mesmo: "acabei de reler esse livro e o achei tão bom! Será que eu posso manifestar essa opinião?” [risos]. Isso acontece com canção o tempo inteiro, gosta-se de coisas que é difícil dizer que a gente gosta. Se partirmos da noção de que nada tem valor intrínseco, ficamos livres para gostar do que quisermos. Depois é que vamos explicar as razões deste gosto, mas antes, podemos exercer o gosto com liberdade. Não há nada que denigra a obra dentro dela, nada. O resto são outras questões, se você "chapou", se você apresentou bem ou não as intenções, se teve tempo de interpretação decente ou não etc. Mas é possível sentir coisas boas por trás de realizações aparentemente retrógradas ou demasiado populares. Aliás, o que nos incomoda não é exatamente a popularidade, mas o caráter comercial. Talvez por sermos muito afastados do universo comercial, de fato, marginalizados com relação a ele. Daí, tudo que nos lembra esse universo nos dá raiva, porque nós não estamos no comércio, nós queríamos poder ganhar dinheiro, participar deste comércio, ter dinheiro à vontade e não conseguimos ...[risos] Tenho a impressão que há um lado meio freudiano nessa repulsa da elite ao mercado.

$B R$ - A propósito do viés psicanalítico, no modelo semiótico em que você articula sua proposta teórica há uma certa recuperação de aspectos das formulações freudianas, especialmente no que diz respeito aos mecanismos de tensividade, de relação com o desejo, dos movimentos do sujeito na construção do sentido serem marcados por pulsões de atração e repulsão etc. Ainda há pouco você apontava que a adesão às canções, em grande medida, se dá num plano que é irracional, gostamos delas sem saber o porquê, e até sem querer. Na abertura do seu livro $O$ cancionista [1995], você menciona a aparente espontaneidade dos compositores populares, capazes de criar canções em mesas de bar, em guardanapos de papel, mas assinala o quanto, por trás deste gesto de realização instantânea, haveria de lenta maturação, de sedimentação, das canções que poderiam ter sido compostas e não o foram, até sair aquela obra no guardanapo, como num passe de mágica. Haveria então uma espécie de "inconsciente coletivo" que se filtra através do gesto de composição do 
cancionista, transformado num arauto da comunidade na qual ele transita. Por outro lado, no fecho de seu livro, você escreve que "a canção brasileira ocupa hoje um espaço artístico amplo demais para permanecer desvinculado de qualquer esfera de reflexão no país". Como você combina essa aspiração teórico-metodológica à suspensão do valor, à abordagem cientificamente neutra, ao desenraizamento dos objetos (ao menos num primeiro momento) do contexto do mercado e da problemática dos níveis de elaboração, que é a vocação de sua abordagem científica da canção, com sua profunda valorização, que transparece em seu trabalho, como um modo de expressão de uma identidade cultural das comunidades nas quais esses cancionistas se enraizam de maneira muito forte? Como combinar a abstração da neutralidade científica ao reconhecimento e ao exame da historicidade da canção e dos cancionistas?

$L T$ - Há vários aspectos em jogo nesta questão. Creio que uma canção, como qualquer produção, só se "completa" quando está em relação com todos os demais fatos culturais produzidos pela comunidade em que se insere. Essa é a "canção final". Em todas as formas de produção acontecem esses dois movimentos: cada objeto específico está em relação com tudo o que ocorre em volta; por outro lado, esse objeto específico vai formando sua própria história e, nela, aparecem certas constâncias que saltam aos olhos. Não há canção que não tenha letra e melodia; não há canção que não tenha velocidade, mais lenta ou mais acelerada. É uma gramática que vai se constituindo. $O$ sentido de um texto que temos diante dos olhos só se depreende se o associarmos ao de outros textos que o cercam, seja o caso de textos impressos, visuais etc. No entanto, ali existe uma gramática de construção que é da língua, constante em todos os textos. Com a semiótica, creio que obtemos elementos para analisar este aspecto gramatical das canções. Com isso, começamos a perceber quais são as formas de unir elementos culturais à nossa interpretação. Evidentemente, qualquer compositor, ao lançar-se à sua obra, traz toda uma carga semântica dentro de si, a escolha do tema, por exemplo. Isso o modelo não resolve: por que ele falou disso, e não daquilo? Mas o modelo revela que o assunto escolhido tem dentro dele "junção / conjunção e disjunção". Isso todos os assuntos têm. Não dá pra explicar as razões de se falar da saudade da namorada ao invés da saudade do violão, mas a idéia de saudade está posta em ambos os casos, é a noção da perda. Mesmo quando os elementos culturais são incorporados à análise, é sob esta perspectiva: o que há neles de permanente? O que faz 
parte da gramática do conteúdo. Por isso creio que a narrativa é a grande solução para a análise do conteúdo. Ele tem uma gramática, e ela é de natureza narrativa. É o sujeito que perdeu o objeto. Disso não há como escapar. Qualquer abordagem do conteúdo, se quiser constituir-se com alguma solidez, precisa recorrer a uma estruturação narrativa, do contrário ficamos falando sobre a fala, o que é muito comum em teoria literária e na própria literatura: pode-se dizer o que quiser. Ali estamos livres para associar autores entre si, idéias, noções, com máxima liberdade. A contribuição da semiótica com o modelo narrativo me parece ser a seguinte: algumas coisas simplesmente não vêm ao caso no processo de análise. O princípio de "pertinência" surge com a lingüística, essa é a questão. Começou com a fonética e a fonologia, depois seguiu para o plano do conteúdo e, atualmente, está bem instalado na teoria narrativa. Ela explica porque "eu me mexo". Um filme em que não acontece nada, em que a personagem não perde nada não é viável narrativamente. Não dá pra imaginar um filme que começa com uma pessoa sentada numa cadeira e nunca se move. $O$ espectador fica esperando que aconteça alguma coisa, senão o filme não se sustenta por mais de dez minutos. $\mathrm{Ou}$ cai uma estante para a personagem se levantar e ver o que aconteceu ou alguém bate na porta... algum incidente tem que criar a narrativa. Nós vivemos entre a harmonia e o sentido: harmonia é termos o objeto dentro de nós, a raiz das palavras sujeito e objeto é a mesma, é o elemento jectal, é o verbo jéter do francês, é lançar, jogar; esse elemento jectal, se você tem "objeto", é porque o antepusemos, se temos "sujeito", é porque introduzimos algo internamente. Assim, tal elemento é interessantíssimo para compreendermos a narrativa. Se tudo está dentro de nós, temos o "objeto" dentro de nós, não há razão para movimento, a narrativa se neutraliza naquele momento. Se nós perdermos o "objeto", temos que ir em busca dele, então ganhamos o sentido, perdemos a harmonia mas ganhamos o sentido. Vivemos neste processo, momentos de harmonia provisória e momentos de busca de alguma coisa. Isso se expressa nas canções, o tempo inteiro temos perdas, que nos fazem procurar dar sentido à história e ao mesmo tempo temos momentos, ora no final, ora no começo, de pequenas harmonias. Tenho a impressão de ser esta uma matriz que serve para pensar qualquer conteúdo, o social, o histórico, da própria comunidade em que se insere o compositor, em todos eles, o que existe de constante é o fato de o sujeito ganhar e perder coisas, o fato de ele estar em conjunção ou disjunção com uma série de objetos. Aperfeiçoar esse modelo narrativo é atingir de frente esse conteúdo - essa é, 
na verdade, uma descrição muito superficial da modelagem a que me refiro, há todo um refinamento na matriz de análise que explica bem mais do que estes aspectos que estou mencionando - mas isso já dá idéia de suas potencialidades para a análise musical. Quando uma peça musical "perde" seu "motivo", é preciso reencontrá-lo, daí o ouvinte se entusiasmar com a música e seguir em busca do elemento "perdido" no início. Toda a música ocidental operou sobre este padrão, que também vemos numa grande obra literária. $O$ conteúdo também precisa desta gramática e o que a semiótica faz é revelá-la, tanto na sonoridade quanto nos elementos textuais, que são fundamentalmente os mesmos.

Adalberto Müller - O discurso metafórico, de natureza essencialmente analógica, não seria uma contraprova dessa concepção de narrativa?

$L T$ - É preciso ter claro o conceito de narrativa em jogo. Neste contexto, narrativa é a passagem de um estado a outro, não estamos pensando em personagens, espaço etc. Basta haver uma transformação, mesmo num quadro abstrato, quando passamos de uma cor para outra, de traços angulosos para sinuosidades, já temos transformação, isso já é narrativa. Entretanto, o que está por trás da narrativa? O tempo, esta é a questão básica. A metáfora nada mais é do que um salto e uma fratura no tempo. Você vincula o conteúdo de uma área ao de outra, que devem ter, em geral, um ponto de passagem, do contrário não entendemos a metáfora, fazendo com que rapidamente uma idéia leve a outra. Se Iracema tem "lábios de mel", é preciso entender que há uma idéia de doçura que permite compreendermos que os lábios dela não são de mel mas sim "doces como o mel". Produz-se um salto. A metáfora é sempre uma questão de velocidade na passagem de um ponto a outro, que nada mais é do que uma transformação abrupta, uma narrativa extremamente acelerada. Coisa que não acontece com a metonímia, onde temos uma narrativa gradativa, para chegarmos à coisa, é preciso percorrer o percurso dela própria, nela sempre estamos num corpo comum, do qual tomamos consciência paulatinamente. Um tex to é compreensível por nós seguirmos sua "metonímia", tudo o que nele lemos é parte dele como um todo, trata-se de uma relação metonímica, portanto. De repente surge nele uma metáfora: então vem o salto. A metonímia garante certa desaceleração, permitindo uma compreensão gradativa; a metáfora opera o salto, de tempos em tempos, que é uma das possibilidades culturais, não apenas em nossa cultura. Em suma, aceleração e desaceleração, nada mais musical do que metáfora e metonímia. 
$A M$ - É a célebre distinção de Roman Jakobson entre prosa e poesia, onde a primeira tenderia à metonímia e a seguinda à metáfora?

LT - Exatamente. Pra ser mais “rápida", 'a poesia tende à metáfora, uma vez que ela é breve, tem curta extensão, precisa transmitir os conteúdos mais velozmente. A metonímia da prosar é precisamente uma busca paulatina dos valores, uma conquista gradativa, sempre foi esse o discurso da prosa. Já a poesia precisa saltar, por vezes há duas, três palavras apenas, é preciso atingir tudo nestas poucas palavras, é preciso ser rapidíssimo. Há, portanto, uma questão de velocidade subjacente que é a mesma da narratividade.

$B R$ - Haveria alguma especificidade na canção brasileira, que a distinguiria de outras linhagens cancionísticas, digamós, como a dos compositores da Broadway dos anos 20 e 30 , Cole Porter, os irmãos Gershwin, Irving Berlin etc., ou a dos franceses, desde Maurice Chevalier até Jacques Brel? Há um grão peculiar à nossa canção?

$L T$ - Como nunca examinei o trabalho destes cancionistas não posso ser afirmativo, mas desconfio que haja esse diferencial, sim. A matriz que vem dos Beatles, que já analisei, é quase didática nos seus modos de expressão, quanto a esses valores naturais da canção. Arrisco sugerir que haja certo paralelismo entre essas manifestações mencionadas. Assim como os Beatles eram excelentes melodistas, nós temos na música brasileira grandes melodistas, como Caetano Veloso, Chico Buarque, José Miguel Wisnik. Temos aqui também cancionistas que derivam para uma diç̧ão "falada", como o Jorge Benjor, ou ainda, embora com menos qualidade para o meu gosto, o Zé Ramalho. No contexto norte-americano, Bob Dylan faz a mesma coisa, uma tendência derivada da fala bruta. Desconfio que não tenha muita diferença... Cole Porter com suas melodias belíssimas, sempre associadas àqueles textos que, sob certo aspecto, aproximam-se do padrão da bossa nova: são sempre narrativas do encontro, da alcgria, da satisfação. Aliás, acho que talvez essa seja uma constância na canção universal, que às vezes fica um pouco adormecida, mas sempre retorna: a busca da conjunção. As letras são sempre celebrações de um encontro. Isso é claro em Cole Porter, onde as letras são líricas e saúdam o encontro. Mesmo quando há perda, ela logo será reparada em seguida. O mesmo acontece com os Beatles, se a felicidade ainda não chegou, vai chegar em breve, ou já houve, mas é sempre uma celebração do encontro. A bossa nova aqui, o que fez foi eliminar aquela 
tendência ao sofrimento que a música anterior estava começando a ganhar com os sambas-canções, os boleros, Lupicínio é a própria encarnação disso, quis-se então voltar à questão do "amor, sorriso e [d]a flor". Esse título de LP é muito claro: é a busca da conjunção, em bossa nova você não pode falar de coisas dramáticas, João Gilberto é muito didático neste sentido: se a música tem um componente dramático ou obscuro, ele não canta. Por exemplo: é sintomático que a canção de Gilberto Gil "Toda menina baiana" é uma das músicas mais interessantes que ele já ouviu; mas se perguntam por que ele não a gravou, a resposta é que há nela um verso de que ele não gosta, "primeiro índio abatido". Ele não consegue dizer uma frase assim... [risos] É interessante isso, no fundo, as canções buscam uma plena conjunção, tenho a impressão de que seja isso que esteja por trás delas. Se a música é acelerada, então a conjunção já é feita no refrão; se a música é desacelerada, a tendência é formar-se uma continuidade de busca do objeto de tal forma que ele seja gradualmente alcançado, às vezes dando saltos, em pequenas acelerações, passando por uma outra região de tessitura, mas com o objetivo final da conjunção. É difícil uma canção que louve a disjunção, é muito raro.

$R B$ - E a ironia? Por exemplo, a tua "Felicidade"?

$L T$ - Aí acho que seria preciso uma outra pessoa para analisar... [risos] É, eu também não entendo isso...

$R B$ - É o título do $\mathrm{CD}$, inclusive...

$L T$ - Pois é, e eu não vejo felicidade, senão em uma canção, "Deu pane em São Paulo", que eu sinto que captou o clima do que eu queria dizer, que é uma música feliz. O resto não é, fico o tempo inteiro problematizando...

$L B$ - No "Deu pane..." mesmo, é a felicidade numa situação impossível, que é quando a cidade pára. Aliás, recuperando sua ligação com São Paulo, sua vinculação ao Rumo, nos anos 80 , um grupo tão paulistano, remete a uma atividade sua como cancionista que é anterior. Em seu livro O cancionista, você data seu insight, aliás "um susto", sobre a natureza da canção, de 1974. Antes disso você já compunha? Esta descoberta afetou seu modo de compor também?

$L T$ - Eu tinha muita prática de compor à maneira dos anos 60 , no estilo dos festivais, etc. Eu já tocava violão desde cedo e sentia que o que eu 
tocava dava pra fazer aquele tipo de música. De 1967 ou 1968 até 1970 devo ter feito mais de 200 músicas, registradas em gravador, como se fosse um tesouro, depois joguei tudo fora [risos]... Naquele momento eu tinha aquilo guardado como se fosse uma grande coisa. Isso me deu prática de composição, conseguia fazer até com uma çerta rapidez, era meio exigente, pra achar que estava acabado, pra mostrar, cheguei a fazer muitos shows com esse repertório, juntamente com o Hélịo Ziskind, que antes mesmo do Rumo já tocava comigo. Depois veio $\rho$ impacto da entrada na Escola de Comunicações e Artes da USP, porque lá eu vim a saber que aquilo "não era música", tudo que eu tinha feito até então não era música, aliás, não era nada, era bobagem, eu tinha perdido meu tempo. E eu tinha entrado ali para me aprimorar, pra incorporar elementos que enriquecessem minhas composições. Daí é que fui aprender desde solfejo até harmonia, pois até então fazia tudo de ouvido, e isso mexeu com o meu modo de compor. Parei por um certo tempo de me apresentar, mas ao mesmo tempo eu me dizia "não gosto disso que estão me ensinando, eu gosto daquela outra coisa...", esse era um problema de muitos de meus colegas ali, mas pra mim teve um impacto profundo, pois eu já lidara muito com composição. Daí surgiu essa indagação sobre alguma forma de compreender o que eram aquelas canções, sua linguagem, embora eu não tivesse a mais remota clareza do que é minha visão hoje, dessa junção de letra e melodia. Eu achava as canções muito fracas, muito bobas, tanto que não compus mais, perdi o entusiasmo, não quis mais fazer aquilo. Ao mesmo tempo eu via as pessoas de que eu gostava, como Chico Buarque, Caetano Veloso, continuando a compor, e eu gostava daquilo, até me perguntava: "se eles parassem também, e sofressem como eu... [risos] será que eles não sabem disso?" Eu me lembro de ter ido conversar com Augusto de Campos sobre isso mas evidentemente ele também não tinha a resposta. Mas como ele era muito amigo do Caetano, eu pensei que ele pudesse ter alguns influxos do Caetano... Na ECA, havia o Willy Correa de Oliveira, que era radicalíssimo em relação à música de vanguarda e era muito amigo de Augusto de Campos, pois tinha composto sobre poesias dele, e fez a minha apresentação. Tinha 17 anos, fui me encontrar com o poeta que me recebeu muito bem, conversamos muito sobre música, e eu ia the perguntando se não haveria algo de especial na canção popular, pois tinha gostado do livro Balanço da bossa [1968], ainda na primeira edição, antes das Outras bossas [1974] que ele incluiu mais tarde, mas o que ele me disse foi que só valeria a pena compor algo se no trabalho houvesse 
qualquer coisa de inovador, que a música parara em [Anton] Webern, que depois disso só aparecera John Cage e, com algumas concessões, [Alban] Berg ou [Karlheinz] Stockhausen. Contudo, a conversa foi muito proveitosa, pois ele falou de outros assuntos, do convívio dele com Caetano e que ouvira dele que gostava muito de conhecer as coisas que os poetas de vanguarda estavam fazendo, mas não faria aquilo de jeito nenhum. Daí fiquei com a pulga atrás da orelha, afinal de contas, Caetano nunca foi tolo, por que será que ele não se envolveu com esse caminho experimental? Seria a linha que Arrigo [Barnabé] queria que ele tivesse seguido... Passado algum tempo, antes da época a que me refiro em meu livro [1974], fiquei anos ouvindo música com a intenção de identificar o que acontecia ali. Ao mesmo tempo, estava programando o Rumo, ou seja, o grupo já existia, mas naquela época a grande dificuldade para se fazer um espetáculo era dispor de aparelhagem de som. Chega a ser engraçado, as dificuldades eram muito práticas. Houve uma ocasião $\mathrm{em}$ que cheguei a marcar um show e até a véspera do espetáculo o equipamento não tinha aparecido. Fomos salvos por um arranjo de amigos que nos emprestaram um amplificador, cantamos com uma caixa de guitarra, tudo muito precário, quase uma coisa familiar. No ano seguinte, antes de o grupo efetivamente começar a sua trajetória, fiquei trabalhando o ano todo num escola de música e tudo o que ganhava, investia em equipamento, ia na rua Santa Ifigênia, onde se concentrava esse comércio, e um amigo meu que estudava engenharia ia construindo uma aparelhagem própria [risos], que era o caminho mais barato para conseguir comprar esse material. Imagine só, naquela época estava convencido de que isso ia durar por toda a minha vida, e hoje de mês a mês muda toda a tecnologia [risos]. Foi um ano inteiro visitando a rua, com meu amigo do lado, e ele fez um belo equipamento. Quando conseguimos aquele lastro, nós iniciamos oficialmente o Rumo, já no final de 1973. Quanto às composições, o que iríamos fazer? Eu já pensara muito naquilo, ficava ouvindo música nas férias, às vezes escrevia algo, discutia com os colegas, especialmente com o Hélio [Ziskind], e foi quando veio o tal insight, estava ouvindo o Gil cantando aquela música "Não sou de briga, mas estou com a razão...", num show memorável na Poli [USP], que ele fez só com violão, ele tocava brilhantemente bem e cantava essa música de uma forma que sentia que ele falava a canção, construindo até as personagens. $O$ salto veio disso, perceber não apenas nessa música, onde ficava evidente, mas em todas as outras músicas, que por trás de tudo havia essa dimensão da fala no interior das melodias. Então, a 
novidade na canção seria explicitar essa natureza, mostrar que isso existe em todas as canções. Isso resolveu o caminho para as composições do grupo. Assim você tem razão, as duas coisas ocorreram mais ou menos simultaneamente: ao mesmo tempo em que eu encontrava a base para fazer prosperar um modelo de análise, encontrei uma fórmula de composição. Isso teve vantagens e desvantagens: realmente saiu uma música nova, estranha; a desvantagem é que as canções ficaram muito duras, por explicitar demais uma teoria. As composições iniciais demoraram para amolecer. Os primeiros discos saíram após seis anos, já havia ocorrido uma triagem. As músicas do começo foram abandonadas todas, a primeira música que ficou foi de 1975, "Ah..."; a segunda foi "Carnaval do Geraldo". Depois começaram a surgir músicas simples e fáceis, que tinham a entonação mas não precisavam explicitá-la tão evidentemente...

$L B$ - E "O encontro"?

$L T$ - "O encontro" é uma música que foi abandonada, mas chegou a ser gravada, porque tinha sido feita às vésperas da gravação e sempre que você acaba uma música ela parece ótima [risos]... com o tempo você vai relativizando...

$L B$ - Pelo menos pra mim, como ouvinte, essa música teve um impacto enorme, precisamente pela explicitação tão nítida desse caminho, que você continua seguindo até certo, o coloquial levado ao extremo, não é mesmo?

$L T$ - É... também não tenho uma opinião formada sobre isso. $O$ certo é que numa certa época, não sei bem se eu ou o Rumo, resolvemos tirar do repertório. Porque o grupo tinha um lado meio "fascista", quando eles decidiam que a música não era boa, faziam aquele arranjo com um "entusiasmo", que logo me convencia a excluir a canção. Às vezes era ruim, quase descartamos coisas importantes...

$L B$ - Por exemplo...

$L T$ - "Odete" ["Olhando a paisagem"]. Quase ficou fora na primeira apresentação. $O$ pessoal achava que aquele momento do show estava muito chato, muito na base de voz e violão, e músico gosta mesmo é de tocar, quando o conjunto saía de cena e eu tocava sozinho, o pessoal ficava dizendo "isso é muito chato etc." [risos]. Pra eles já não tinha graça aquela história toda e eles queriam que passasse logo. Era uma seqüência 
que começava com uma individual de meu irmão [Paulo Tatit], e depois eu entrava com mais três em seguida... Pra eles era muito longo, muito chato, quase que a canção saiu. Mas eu sugeri que a gente experimentasse uma na primeira vez. Foi uma loucura, nós nos apresentamos no Sesc Pompéia, e o teatro veio abaixo quando acabei de cantar a música, o pessoal disse com tamanho entusiasmo Odete no final, um grito só, que foi uma surpresa pra nós, ninguém sabia que a música tinha aquela força. Eles desprezavam um aspecto da música que lhes parecia banal... Pra ver como a gente não sabe se a música é boa ou não antes de apresentá-la a um público. É difícil, certas músicas eu achava muito boas e não deram certo, outras vezes era o contrário. E por vezes a gente também acerta.

$A M$ - Como na literatura, ou nas outras artes, é o leitor que faz a obra...

$L T$ - A gente não sabe o que acontecerá na cabeça do outro exatamente.

$B R$ - Você reconhece esse papel do público, vale dizer, do mercado, na construção e validação das canções, aliás como Caetano Veloso sempre o fez, e bem ao contrário da postura de José Ramos Tinhorão. Num artigo recente para o caderno Mais, dedicado à emergência do consumo de uma classe social anteriormente mais pobre, constituindo um novo mercado, creio que você utiliza apenas uma vez esta palavra, mercado, referindo-se freqüentemente à sociedade. Não sei se essa escolha vocabular é consciente ou não, mas parece relevante, não é mesmo?

$L T$ - De fato, não acho que seja uma exigência do mercado, mas sim da sociedade. Esta demanda conteúdos, não são as pessoas das gravadoras que vão determinar essa necessidade. Não sei de onde ela vem, mas não é dos executivos da indústria do disco. Certos artistas voltam a gravar, tocam uns nos discos dos outros, a gente sente que está acontecendo como resposta, mas de onde vem esta exigência? É um conteúdo que está faltando. Por exemplo: no auge do rock brasileiro na década de 1980, ninguém poderia imaginar que fazia falta a música sertaneja. Foi algo inesperado, alguém testou, talvez ainda como dupla caipira, de repente aquilo começou a entrar no gosto popular, daí virou uma coqueluche nacional, uma coisa que já estava adormecida, que achava-se que não existia mais no Brasil. Houve uma demanda de algum lugar, mas não das gravadoras, pois pra elas, o mais interessante seria produzir as músicas norte-americanas. $O$ menor custo estaria na internacionalização da música americana, lançando aqui os discos que já estavam prontos lá, como era antigamente. Agora é preciso fazer produção, formar o artista... 
como eles descobriram isso? Alguém exigiu. Creio então que a comunidade exige coisas, conteúdos melódicos de que ela sente falta. Se é sertaneja, é porque nela o arranjo é mais simples, pode-se gravar mais discos, a produção é barata, acabou sendo essa a resposta. Talvez por não existirem 10 ou 20 Djavans. Se existissem, já haveria música romântica de sobra. Numa gravadora, para construir-se um artista, é preciso começar por algo simples: ou é uma dupla sertaneja, ou é uma banda de rock, ou ainda um grupo de pagode. Não dá pra fazer nascer um Caetano toda hora, ou um Erasmo Carlos... então ficam aqueles grupinhos que seguem a orientação dos executivos. Penso que é realmente uma exigência da comunidade que aquele conteúdo seja preenchido, daí a gravadora procura a forma mais barata de responder à demanda.

$B R$ - Gostaria de retornar ainda uma vez à questão dos "registros" aos quais se dirigem os diferentes produtos no cenário da canção, os níveis de consumo aos quais as canções são destinadas. Consideremos o caso de um artista como Antonio Nóbrega: em seu espetáculo Na pancada do ganzá [1996], não era raro vermos muitos pais levando scus filhos, a despeito dos horários serem os de um show para adultos, e as crianças, muitas vezes acomodadas em colchonetes e esteiras à beira do palco, vibravam com sua combinação de dança, encenação e performance musical. Num dado momento da apresentação, por sinal, Nóbrega assinalava didaticamente: "Depois vão dizer que as pessoas só gostam dos gêneros de música que tocam nas rádios...". Já conheci crianças que são fãs ardorosas do trabalho do Rumo, assim como do Karnak. De fato, conheci algumas que vibravam com o primeiro disco da banda do Abujamra da mesma forma com que o faziam com os Mamonas Assassinas, que apareceram mais ou menos na mesma época. Em que medida as canções, como as demais formas de expressão artística, a despeito de serem pensadas ou trabalhadas tendo em vista certos recortes de público, podem escapar a essas delimitações e tocar platéias em princípio inesperadas?

$L B$ - Mas elas precisam “tocar para poder tocar"...

$P C$ - De certa maneira, elas são feitas para qualquer um...

$B R$ - Será que há como controlar o que há de atingir ao público?

$L T$ - Nem nós, nem o mercado pode controlar isso. Eu também não vejo diferença entre o Karnak e os Mamonas Assassinas [risos]. Imagino que 
eles gostariam de ser tão populares quanto os Mamonas. Mas o que impulsionou isso, o que faz essa diferença, não dá pra saber exatamente. Às vezes uma gravadora pode achar que o Karnak poderia obter o mesmo tipo de sucesso, mas invista e nada aconteça. E no entanto, eles podem continuar seguindo nesse ritmo lento e, de repente, acontecem como fenômeno.

$A M$ - Há todo um público novo, dos Mamonas, do É o Tchan!, que cresce muito e está determinando os rumos da produção...

$L T$ - É verdade. O Nóbrega tem razão quanto ao fato de que, caso ele tivesse mais chances de se apresentar, certamente seu trabalho seria muito mais popular, são coisas supergenuínas, poderiam ser muito aproveitadas e, de fato, as crianças adoram esse tipo de trabalho. Por outro lado, ele não tem razão em recriminar o que toca por aí, uma vez que ele tem uma certa aversão a tudo o que não tenha um caráter autêntico, não tem valor, é deturpado, produto de mercado etc. Isso não é verdade, uma vez que os elementos do pagode, da axé music, são populares também, todos vieram da Bahia, todos vieram do Recife, todos vieram de lá também. Eles apenas plastificam seus produtos, pois têm que produzir muitos iguais, em larga escala, mas não deixam de ser populares, e até mais importantes, na atual conjuntura, pois tomaram conta do mercado, superando inclusive a música estrangeira. Quanto à questão do espaço, todos reclamamos, se tivéssemos mais espaço, apareceríamos muito mais etc. Mas para discutirmos o mercado temos que entrar em uma outra esfera. Lembro de um show de Gilberto Gil na Poli [Engenharia da USP], por volta de 1972, quando ele estava numa fase muito mística, que desembocou em Refazenda, Refavela. Ele estava tocando uma barbaridade nesta época, este foi um espetáculo antológico, creio que nunca mais ele fez um show como aquele. Das músicas que ele tocou então ele já não lembra mais, sejam as dele, sejam as arranjadas por ele. Meu irmão e eu tínhamos conseguido uma fita com as apresentações dele na época. Há alguns anos o Gil nos pediu para tentar recuperar este trabalho, de que ele já nem lembrava mais. Num determinado momento do espetáculo, ele começou a conversar com a platéia e os estudantes começaram a exigir dele uma posição política, ele acabara de retornar do exílio e tudo o mais. Gil estava muito místico, fazendo macrobiótica, e não estava nem aí com as questões da política imediata, vivendo numa perspectiva hippie, de uma maneira verdadeiramente religiosa. Nessa época, o público uspiano exigia uma participação social, 
afinal "de que lado ele estava?", "e se não promovem mais a sua música?", "e se você não tiver mais espaço, continuará compondo?". A resposta de Gil foi a seguinte: "Eu procuro compreender um pouquinho mais um trechinho bíblico que diz assim: dai a César o que é de César e dai a Deus o que é de Deus. Eu vou fazer música sempre, sendo promovido ou não; o que farão com a minha música, é problema de César..." [risos] É interessante isso, pois revela a posição de um artista que, ao invés de reclamar dos limites do mercado, ou mesmo da sociedade no sentido mais amplo, prefere pensar que pode fazer uma parte, a sua parte, que é espiritual, compor e apresentar ao público suas canções em espetáculos. Agora, quem vai pôr dinheiro, investir, nisso não vale a pena nem pensar. Concordo com essa perspectiva, acho que é mais ou menos assim, embora eu tenha uma certa satisfação em pensar nessa questão do mercado, verificar se é possível identificar leis que regem o seu funcionamento, passo mesmo muito tempo conversando com pessoas como o Celso Masson, da Veja, a respeito disso. Embora não cheguemos nunca a uma conclusão, ao menos os problemas formulados podem aparecer em suas matérias sobre o tema. Mas como compositor, pra mim tanto faz o lado para o qual as coisas forem, se prestigiarão mais ou menos a minha música, ou de quem quer que seja. Tanto faz; do que está aí eu gosto, e gostaria que houvesse mais oferta de variedade, mais coisas de que pudesse gostar e pelas quais pudesse vir a me interessar. Mas preferia que isso fosse um processo espontâneo, sem esse negócio de ter que "lutar pra tocar", senão a gente fica doido.

$L B$ - O Rumo fez algum esforço nesse sentido? Chegou a aparecer um clipe da banda no Fantástico, da canção "O suicida" [Zé Carlos Ribeiro].

$L T$ - Isso foi uma iniciativa do Olhar Eletrônico, uma produtora de televisão independente que já tem uma certa reputação comercial hoje em dia, mas naquela época ainda era um grupo alternativo. $O$ Fantástico estava precisando mudar um pouco sua linguagem e eles foram procurados, já que faziam coisas mais audaciosas, menos previsíveis. Acho que foi uma indicação do Maurício Kubrusly, que era muito ligado à gente e a esse circuito independente. E dessa coincidência surgiu a idéia do clipe. Nem sei se a escolha da música foi boa, pois essa canção era meio dura, pouco popular, era interessante para fazer imagem, mas soava difícil. Não partiu de nós, portanto. Aceitamos imediatamente, mas não propusemos nada. Todas as aberturas que surgiram no mercado nós aceitamos, mas foram muito poucas e algumas até tentamos estimular, 
pra verificar se o problema éramos nós ou o mercado. Lembro que ao trabalharmos no disco Caprichoso, chegamos a mandar uma fita para o André Midani, que dirigia a WEA na época, e ele foi explícito: muito educado, devolveu o material com uma carta onde dizia ter gostado muito das músicas, mas não estamos trabalhando com este gênero; se viermos a trabalhar, faremos contato. Ficou nisso até hoje... [risos] A gente entende. Na mesma época, os Titãs estavam tentando a mesma coisa, mas agiram de outra maneira. Mandaram uma fita para o Liminha, com um trabalho que já era mais palatável de saída, meio à maneira de Roberto Carlos, tanto que eles se chamavam ainda Titãs do iê-iê-iê, e receberam como resposta algo parecido, só que mais detalhado na recusa, com certas sugestões quanto à instrumentação, modo de cantar etc., e eles aceitaram, mudaram tudo e apresentaram de novo. Daí logo gravaram e deu certo...

$L B$ - Por um tempo...

$L T$ - Exatamente. Quando eles tentaram fazer o que realmente queriam, que era o rock pesado, do Titanomaquia, quase se dissolveu o grupo. Daí eles tiveram que beber no brega, que é o que eles até então evitavam. E eles sabem fazer boas canções, são super hábeis, especialmente o Paulo Miklos, o Nando Reis e o Sérgio Brito, e imediatamente vieram coisas como "é cedo ou tarde demais...", que é brega explícito. Até gosto da música. Mas ouvindo cem vezes já cansa um pouco. Mas é muito bem cantada pelo Miklos, depois veio o Aclistico, foi preciso preparar tudo muito bem, e deu uma explosão que nem eles esperavam mais.

$L B$ - Pensando que uma das formas de entrar no mercado é ser interpretado por outras pessoas, isso aconteceu com as canções do Rumo?

LT - A Daúde gravou o "Ah!...", e acho que é a melhor de todas as gravações dessa canção. Ela já fora gravada pelo Rumo e pela Ná Ozzeti, mas a gravação da Daúde é brilhante. Um arranjo excelente, muito bem interpretada. Penso que essa é uma tendência, as pessoas gravarem músicas que de outra forma teriam dificuldade de entrar no circuito maior. De repente o sucesso do disco do intérprete acaba carreando algum prestígio para a canção e abrindo novas oportunidades. 